\title{
Soybean Yield and Yield Component Response to Plant Density in Narrow Row Systems
}

Michael Epler and Scott Staggenborg, Department of Agronomy, Kansas State University, Manhattan, KS 66506

Corresponding author: Scott Staggenborg. sstaggen@ksu.edu

Epler, M., and Staggenborg, S. 2008. Soybean yield and yield component response to plant density in narrow row systems. Crop Management doi:10.1094/CM-2008-0925-01-RS.

Accepted for publication 7 July 2008. Published 25 September 2008. 


\title{
Soybean Yield and Yield Component Response to Plant Density in Narrow Row Systems
}

\begin{abstract}
Soybean (Glycine max) yield is responsive to changes in plant population and row spacing under dryland conditions. Soybean seeding rate recommendations in many states were developed prior to the release of herbicide tolerant varieties when soybean seed costs were lower. As a result, many recommendations are high, and soybean performance at low plant densities in narrow rows needs to be reevaluated. This study was conducted to evaluate soybean yield response to plant density in narrow row, drilled systems (7.5 and 15 in) and evaluate the effects of plant population on yield components. The study was conducted in six environments with optimum plant populations ranging from 80000 to 140000 plants acre ${ }^{-1}$. The two yield components responsible for the yield optimization were pods plant ${ }^{-1}$ and pods acre ${ }^{-1}$. As plant population increased, pods plant $^{-1}$ decreased steadily; however, yield was not reduced either year of the study by the loss of pods plant ${ }^{-1}$ because pods acre ${ }^{-1}$ increased as plant population increased. The optimum seeding rates for each year of the study were below the 150000 to 160 000 plants acre ${ }^{-1}$ seeding rate normally recommended in the region. The decreased optimum plant populations in both years did not adversely affect yield and might be useful in reducing input costs in dryland soybean production.
\end{abstract}


Soybean yield responses to plant density and row spacing have been studied extensively during the past two decades. Many studies examined physiological responses to narrow row spacing (7.5 in or less) as this management system evolved (Board and Harville, 1992; Buhler et al., 1990; Bullock et al., 1998; Duncan, 1986; Egli et al., 1987; Ethredge et al., 1989; SafoKatanka and Lawson, 1980). Early seeding rate recommendations for soybean grown in narrow rows were quite high $\left(\sim 200,000\right.$ seed acre $\left.{ }^{-1}\right)$, but seed costs were quite low prior to the release of herbicide tolerant varieties (Staggenborg et al., 1996).

Early narrow row soybean research was conducted under conventionally tilled systems with grain drills designed for wheat seed metering and placement. The combination of this tillage system and planting equipment often resulted in low emergence rates. This, combined with low seed costs is likely the genesis of high seeding rate recommendations.

The ability of soybean to compensate for low population has resulted in little or no response to changes in plant population from 70000 up to more than 400000 seed acre $^{-1}$ (Ablett et al. (1991); Adams and Weaver, 1998; Beuerlein, 1988; Costa et al., 1980; Kratochvil et al., 2004; Lehman and Lambert, 1960; Riess and Sherwood, 1965). Devlin et al. (1995) found that yields in Kansas are normally affected by water availability, planting date, and soil type. This illustrates that environmental conditions can contribute to the non-response of soybean yields to increasing seeding rates.

Soybean responds to row spacing and population shifts through yield component adjustments. Carpenter and Board (1997) attributed soybean yield compensation at low densities to increased branching, while others reported that pods plant ${ }^{-1}$ and seeds plant ${ }^{-1}$ were the source of compensation (Ball et al., 2000; Board et al., 1990; Boquet, 1990; Lehman and Lambert, 1960; Norsworthy and Shipe, 2005; Weber et al., 1966). Board et al. (1990) and Bullock et al. 
(1998) reported that early season light interception was the reason for narrow row soybean having higher yields than those grown in wide rows. In wider rows, decreased light interception led to decreased branching, pods plant ${ }^{-1}$, and seeds plant ${ }^{-1}$ which provided the yield advantage in narrow row soybean. These researchers also reported decreased pods plant ${ }^{-1}$, and Bullock et al. (1998) reported decreased branching as row width increased, which suggests that added interrow space does not always translate into increased branches and pods plant ${ }^{-1}$.

Because soybean has the ability to adjust yield components at low plant densities to maintain yield levels, it is possible that soybean seeding rates in narrow row systems can be reduced without reducing grain yields. Therefore, our objectives were to: 1) evaluate yield, yield component, and plant characteristic responses to plant population and row spacing and 2) determine the minimum soybean plant population that can be achieved in Kansas without decreasing yields. 


\section{Field Studies}

This study was conducted in 2005 and 2006. Plots were planted at Manhattan, KS, Ottawa, KS, and Rossville, KS in 2005 and 2006. Table 1 shows the soil series and taxonomic description for each of the locations and years included in the study.

All small plots were sowed with a no-till drill (Model 3P605NT, Great Plains Mfg., Salina, KS) with 7.5 in row spacing. In 2005 and 2006 treatments consisted of five seeding rates: 60-, 100-, 140-, 180-, and 220000 seeds acre ${ }^{-1}$. In 2005, plots had 7.5 in row spacings and in 2006, a 15 in row spacing treatment was added at all locations. At all three locations in 2005, the experimental design was a randomized complete block with four replications. In 2006, a split plot within a randomized complete block design with row spacing as the main plot and seeding rate as the sub-plots was used at all locations. Plot size was 6 by $30 \mathrm{ft}$ at all locations. The tillage system at the 2005 and 2006 Manhattan and Ottawa locations was no-till, while the 2005 and 2006 Rossville locations were planted into a conventional-till system. Table 2 shows the planting date, row spacing, previous crop, and variety of seed used for all locations in 2005 and 2006.

At all locations and both years, final plant population was determined approximately 30 days after planting. To determine plant population, plants were counted on both sides of a $10 \mathrm{ft}$ pipe that was randomly placed between two non-border rows. Pods plant ${ }^{-1}$, with respect to origin on plant (branches or mainstem), plant height, and height of the lowest pod were determined at approximately growth stage R7 by randomly selecting two plants from each plot for measurement. The yield components seeds pod ${ }^{-1}$ and pods acre ${ }^{-1}$ were calculated using the plant populations and the pods plant ${ }^{-1}$, and 200 seeds were counted from every plot to determine seed weight. All 2005 locations were combined for analysis using GLM (SAS v 9.1) after 
variance testing indicated the variances were equal from each location. In 2006, the Manhattan, Ottawa, and Rossville locations were combined for analysis using GLM (SAS v 9.1).

\section{Yield Responses to Narrow Rows}

In this study, the soybean planting dates and seeding rates used included the normal ranges used in Kansas. Across both years, yields ranged from 24 to 64 bu acre ${ }^{-1}$ which was attributed to the wide variation in temperature, soil quality, and rainfall throughout the two years of the study.

In 2005, adequate rainfall was received for much of the growing season, which contributed to the moderately high yields found at all three locations (Fig 1). The adequate rainfall across the region resulted in yield variances that were equal for each of the three locations, so the data were combined for analysis and only plant population affected yields (Table 3). Across all three locations, yields increased as plant population increased until reaching a plateau at 80000 plants acre ${ }^{-1}$ (Fig. 2A).

In 2006, rainfall was not as abundant in the region, and yields were lower than 2005. Locations, location X population and location X row spacing affected yields (Table 3 ). The 7.5 in row spacing produced higher yields at all locations in 2006, and Manhattan and Ottawa both yielded higher than Rossville in 2006 (Table 4). As plant population increased, yield increased in a quadratic manner at Manhattan and Ottawa with optimum yields occurring at plant populations 136000 and 140000 plants acre ${ }^{-1}$, respectively (Fig. 2B). A severe hailstorm at Rossville in 2006 at approximately the V2 growth stage decreased the final plant population and delayed the crop (Table 4). The lower plant densities at Rossville contributed to the significant location X row spacing interaction in 2006 (Table 3). The lower plant densities and delayed development at Rossville in 2006 resulted in a similar yield response to increasing plant 
populations as the other locations. Based on the regression analysis and extrapolation beyond the data, the optimum plant population at Rossville in 2006 was approximately 150000 plants $a^{-1}$. This is not an unreasonable conclusion, as the physical hail damage and delayed development might require more plants to develop adequate pods and grain to reach the yield potential compared with the other two locations where hail was not a factor.

Optimum plant densities of 80000 and 140000 plants acre $^{-1}$ (2005 and 2006, respectively) are below the recommended seeding rates for Kansas (Fjell et al., 1997) and Nebraska (Elmore and Spectht, 2000) who recommend 180000 and 150 000, respectively and in agreement with seeding rates for 30 inch rows in Missouri (Helsel and Minor, 1993). However, our results are reported in plants acre ${ }^{-1}$ and seeding recommendations are made in seed acre ${ }^{-1}$ meaning that emergence rates must be considered. This creates the greatest challenge associated with the seeding rate decision as seeding equipment (drill vs. planter), weather (rain at planting) and seed quality can play an important role in emergence rates.

\section{Pods Plant ${ }^{-1}$ and Pods acre ${ }^{-1}$}

Yield components responded similarly across locations and years. In 2005 and 2006 plant population affected pods plant ${ }^{-1}$ (Table 3). Pods plant ${ }^{-1}$ were different at each location in both 2005 and 2006 (Table 5). Throughout the study, as population increased, pods plant ${ }^{-1}$ decreased in a polynomial manner, reaching minimums from 150000 to 190000 plants acre ${ }^{-1}$ (Fig. 3A). The negative response in pods plant ${ }^{-1}$ to increasing plant population agree with the findings of several other researchers (Ball et al. 2000; Boquet 1990; Lehman and Lambert 1960; Norsworthy and Shipe 2005; Weber et al. 1966).

In 2005 and 2006, pods acre ${ }^{-1}$ were affected by location and plant population (Table 3). Pods acre ${ }^{-1}$ were different across locations both years (Table 5). It appears that the lower plant 
densities and damage to the plants from the hail at Rossville in 2006 had less impact on the plants' ability to compensate than might be expected. Pods plant ${ }^{-1}$ at Rossville were equal to those at Ottawa and greater than at Manhattan. Pods acre ${ }^{-1}$ at Rossville were lower than at the other two locations. As population increased, pods acre ${ }^{-1}$ increased in a linear manner (Fig. 3B). Pods plant ${ }^{-1}$ was not correlated to yield $(\mathrm{r}=0.02)$, but pods acre ${ }^{-1}$ was correlated to yield $(\mathrm{r}=$ 0.72). These results agree with the findings of Parvez et al. (1989), but conflict with those of Ethredge et al. (1989).

\section{Branch Contribution to Total Pods Plant ${ }^{-1}$}

In 2005 and 2006, pods plant ${ }^{-1}$ on branches were affected by plant density (Table 3). As population increased in both years, the percent of branch pods on each plant decreased (Fig. 3C). It was apparent that increased competition within the rows caused the plants to branch less, and therefore receive less of the total yield from branches. Branch pod contribution had a low correlation to yield $(r=0.25)$ but had a larger influence on pods acre ${ }^{-1}(r=0.67)$. These findings agree with work done by Probst (1945) and Carpenter and Board (1997), who showed the compensatory ability of soybeans as they react to increases and decreases in available space.

\section{Plant Height}

In 2005, plant height was affected by plant density at all locations (Table 3). As plant density increased, plant height increased in a quadratic manner, reaching a maximum at plant population of approximately 195000 plant acre $^{-1}$ (Fig. 4). In 2006, plant height was affected by location, plant density, and row spacing as indicated by significant location $\mathrm{X}$ population and location X row spacing interactions for the three combined locations (Table 3). Plant heights 
were not different when comparing the two row spacings at Manhattan and Rossville in 2006 (Table 6). At Ottawa in 2006, plants in the 7.5 in rows were shorter than plants in the 15 in rows.

Plant height was not affected by plant population to the same degree at Manhattan and Ottawa in 2006 as in 2005. In 2005, plant heights across all locations had a range of 4 in, whereas at these two locations in 2006, the range was less than 2 in. In 2006, only at Rossville did plant height increase as rapidly as plant density increased. Plant height in narrow row soybean is often a concern to producers, as taller plants are believed to have greater risk of lodging.

\section{Height of First Pod}

Of greater interest to producers than plant height is the location of the first pod from the soil surface. Across all locations each year, height of first pod was affected by plant population (Table 3). The location main effect was also significant in 2006. In 2005, height to the first pod increased linearly and reached a plateau at approximately 110000 plants acre ${ }^{-1}$ (Fig. 5). In 2006, average height of the lowest pod increased as plant population increased and reached a maximum at approximately 140000 plants acre ${ }^{-1}$ (Fig. 5). These observations agree with the findings of Lueschen and Hicks (1977), who reported similar responses of first pod height to plant population.

\section{Seeds Pod $^{-1}$ and Seed Weight}

Population affected seeds pod ${ }^{-1}$ in 2006 (Table 3) but seeds pod ${ }^{-1}$ were not affected by any treatments in 2005. As population increased, seeds pod $^{-1}$ decreased in a linear manner (seeds 
$\operatorname{pod}^{-1}=2.71-3.21 \times 10^{-6} *$ plant population) with the data ranging from 2.3 to $1.5 \mathrm{seeds} \mathrm{pod}^{-1}$ (data not shown). In both 2005 and 2006, growing conditions at each location affected seed weights differently (Table 3). In 2005, seed weights were different at each location (Table 5). In 2006, the delayed development because of the hail damage at Rossville reduced the time available for grain fill and seed weights at Rossville were lower than those measured at Manhattan and Ottawa. This illustrates that the yield component most affected by the hail damage was seed weight compared with pod plant ${ }^{-1}$ and pods acre ${ }^{-1}$. As discussed earlier, pod acre ${ }^{-1}$ were approximately $10 \%$ lower at Rossville than Manhattan, whereas seed weights are approximately $20 \%$ lower at Rossville compared with the other two locations in 2006.

Seed weight influenced grain yield $(r=0.79)$, but seeds $\operatorname{pod}^{-1}$ did not influence yield $(r=$ -0.06). Seed weight and seeds pod ${ }^{-1}$ yield responses were mainly affected by rainfall and high temperatures late in the growing season after growth stage R5. These findings agree with those of Board et al. (1990) and Lehman and Lambert (1960), who both reported that seeds pod ${ }^{-1}$ and seed weight typically do not display as large of a response to plant density as do the yield components pods plant ${ }^{-1}$ and pods acre ${ }^{-1}$.

\section{Summary}

Row spacing had little effect on soybean yield and yield components, but population and environment played major roles in dictating yield responses. Yields were maintained across changing plant densities due to the compensatory abilities of soybean to fluctuate yield components in response to intra- and inter-row competition. The 2005 plots failed to increase in yield above 80000 plants acre ${ }^{-1}$ and the 2006 plots had optimum plant populations below the currently recommended seeding rates for Kansas and Nebraska and were in agreement with those 
from Missouri. Therefore, it is likely that the recommended soybean seeding rates for dryland environments can be safely lowered by at least $20-25 \%$. 


\section{LITERATURE CITED}

Adams, P.D. and D.B. Weaver. 1998. Brachytic stem trait, row spacing, and plant population effects on soybean yield. Crop Sci. 38:750-755.

Ablett, G.R., W.D. Beversdorf, and V.A. Dirks. 1991. Row width and seeding rate performance of indeterminate, semideterminate, and determinate soybean. J. Prod. Agric. 4:391-395.

Ball, R.A., L.C. Purcell, and E.D. Vories. 2000. Optimizing soybean plant population for a shortseason production system in the Southern U.S. Crop Sci. 40:757-764.

Beuerlein, J.E. 1988. Yield of indeterminate and determinate semidwarf soybean for several planting dates, row spacings, and seeding rates. J. Prod. Agric. 1:300-303.

Board, J.E., and B.G. Harville. 1992. Explanations for greater light interception in narrow rows vs. wide-row soybean. Crop Sci. 32:198-202.

Board, J.E., B.G. Harville, and A.M. Saxton. 1990. Narrow-row seed-yield enhancement in determinate soybean. Agron. J. 82:64-68.

Boquet, D.J. 1990. Plant population density and row spacing effects on soybean at post-optimal planting dates. Agron. J. 82:59-64.

Buhler D.D., B.D. Philbrook, E.S. Oplinger. 1990. Velvetleaf and giant foxtail control for solidseeded soybean production in three tillage intensities. J. Prod. Agric. 3:302-308.

Bullock, D., S. Khan, and A. Rayburn. 1998. Soybean yield response to narrow rows is largely due to enhanced early growth. Crop. Sci. 38:1011-1016.

Carpenter, A.C. and J.E. Board. 1997. Growth dynamic factors controlling soybean yield stability across plant populations. Crop Sci. 37:1520-1526. 
Costa, J.A., E.S. Oplinger, and and J.W. Pendleton. 1980. Response of soybean cultivars to planting patterns. Agron. J. 72:153-156.

Devlin, D.L., D.L. Fjell, J.P. Shroyer, W.B. Gordon, B.H. Marsh, L.D. Maddux, V.L. Martin, and S.R. Duncan. 1995. Row spacing and seeding rates for soybean in low and high yielding environments. J. Prod. Agric. 8:215-222.

Duncan, W.G. 1986. Planting patterns and soybean yields. Crop Sci. 26:584-588.

Egli, D.B., R.D. Guffy, and J.J. Heitholt. 1987. Factors associated with reduced yields of delayed plantings of soybean. J. Agron. Crop Sci. 159:176-185.

Ethredge, Jr., W.J., D.A. Ashley, and J.M. Woodruff. 1989. Row spacing and plant population effects on yield components of soybean. Agron. J. 81:947-951.

Fjell, D.L. 1997. Soybean production handbook. Kansas St. Res. and Ext. Pub. No. C-449. Manhattan, KS.

Kratochvil, R.J., J.T. Pearce, and M.R. Harrison, Jr. 2004. Row spacing and seeding rate effects on glyphosate-resistant soybean for Mid-Atlantic production systems. Agron. J. 96:10291038.

Lehman, W.F., and J.W. Lambert. 1960. Effects of spacing of soybean plants between and within rows on yield and its components. Agron. J. 52:84-86.

Lueschen, W.E., and D.R. Hicks. 1977. Influence of plant population on field performance of three soybean cultivars. Agron. J. 69:390-393.

Norsworthy, J.K., and E.R. Shipe. 2005. Effect of row spacing and soybean genotype on mainstem and branch yield. Agron. J. 97:919-923. 
Parvez A.Q., F.P. Gardner, and K.J. Boote. 1989. Determinate- and indeterminate-type soybean cultivar responses to pattern, density, and planting date. Crop Sci. 29:150-157.

Probst, A.H. 1945. Influence of spacing on yield and other characters in soybeans. J. Amer. Soc. Agron. 37:549-554.

Riess, W.D., and L.V. Sherwood. 1965. Effects of row-spacing, seeding rate, and potassium and calcium hydroxide additions on soybean yields on soils in southern Illinois. Agron. J. 57:431-433.

Safo-Kantanka, O., and N.C. Lawson. 1980. The effect of different row spacings and plant arrangements on soybeans. Can. J. Plant Sci. 60:227-231.

Staggenborg, S.A., D.L. Devlin, D.L. Fjell, J.P. Shroyer, W.B. Gordon, B.H. Marsh, and L.D. Maddux. 1996. Soybean response to row spacing and seeding rates in Northeast Kansas. Pub. No. SRL 112. Kansas Agric. Exp. Stn., Manhattan, KS

Weber, C.R., R.M. Shibles, and D.E. Byth. 1966. Effects of plant population and row spacing on soybean development and production. Agron. J. 58:99-102. 


\section{List of Figures.}

Fig. 1. Cumulative normal precipitation and precipitation measured in 2005 and 2006 for Manhattan, Ottawa, and Rossville, KS

Fig. 2. Soybean yield response to plant density averaged across Manhattan, Ottawa, and Rossville, KS in 2005 (A) and for individual locations in 2006 (B).

Fig. 3. Soybean pods plant ${ }^{-1}$ as affected by plant population at Manhattan, Ottawa, and Rossville,

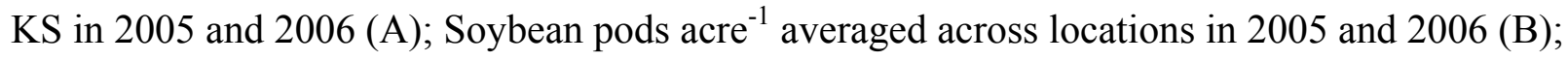
Branch contribution to the total pods plant ${ }^{-1}$ across locations in 2005 and 2006 (C).

Fig. 4. Soybean plant height response to plant density averaged across Manhattan, Ottawa, and Rossville, KS in 2005 (A) and for individual locations in 2006 (B).

Fig. 5. Height of first pod averaged across Manhattan, Ottawa, and Rossville, KS in 2005 and 2006. 


\section{Figures and Tables}

Table 1. Soil series and taxonomic descriptions for all 2005 and 2006 plot locations.

\begin{tabular}{lcll}
\hline Year & Location & \multicolumn{1}{c}{ Soil Series } & \multicolumn{1}{c}{ Taxonomic Description } \\
\hline 2005 & Manhattan & Reading silt loam & Fine-silty, mixed, superactive, mesic Pachic Argiudolls \\
2005 & Ottawa & Woodson silt loam & Fine, smectitic, thermic Abruptic Argiaquolls \\
2005 & Rossville & Eudora silt loam & Coarse-silty, mixed, superactive, mesic Fluventic Hapludolls \\
2006 & Manhattan & Smolan silt loam & Fine, smectitic, mesic Pachic Argiustolls \\
2006 & Ottawa & Woodson silt loam & Fine, smectitic, thermic Abruptic Argiaquolls \\
2006 & Rossville & Eudora silt loam & Coarse-silty, mixed, superactive, mesic Fluventic Hapludolls \\
\hline
\end{tabular}


Table 2. Planting dates, row spacing, previous crop, and soybean variety for 2005 and 2006 soybean plots.

\begin{tabular}{cccccc}
\hline Year & Location & $\begin{array}{c}\text { Planting } \\
\text { Date }\end{array}$ & $\begin{array}{c}\text { Row } \\
\text { Spacing (in) }\end{array}$ & $\begin{array}{c}\text { Previous } \\
\text { Crop }\end{array}$ & $\begin{array}{c}\text { Soybean } \\
\text { Variety }\end{array}$ \\
\hline 2005 & Manhattan & 17-May & 7.5 & soybean & Asgrow brand 3701 RR \\
2005 & Ottawa & 27-May & 7.5 & sorghum & Asgrow brand 3701 RR \\
2005 & Rossville & 20-May & 7.5 & corn & Asgrow brand 3701 RR \\
2006 & Manhattan & 16-May & $7.5 \& 15$ & sorghum & Garst brand 3824 RR \\
2006 & Ottawa & 19-May & $7.5 \& 15$ & sorghum & Garst brand 3824 RR \\
2006 & Rossville & 8-Jun & $7.5 \& 15$ & corn & Garst brand 3824 RR \\
\hline
\end{tabular}


Table 3. Significance levels for soybean plots in 2005 and 2006 at Manhattan, Ottawa, Rossville, and Parsons KS.

\begin{tabular}{|c|c|c|c|c|c|c|c|c|c|}
\hline & $\begin{array}{l}\text { Seed } \\
\text { Yield }\end{array}$ & Plants acre ${ }^{-1}$ & Pods Plant ${ }^{-1}$ & Pods acre ${ }^{-1}$ & $\begin{array}{c}\text { Branch } \\
\text { Pod Percent }\end{array}$ & $\begin{array}{c}\text { Plant } \\
\text { Height }\end{array}$ & $\begin{array}{c}\text { First Pod } \\
\text { Height }\end{array}$ & Seeds Pod $^{-1}$ & $\begin{array}{c}\text { Seed } \\
\text { Weight }\end{array}$ \\
\hline & \multicolumn{9}{|c|}{ 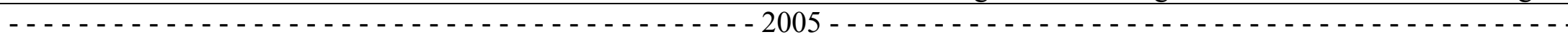 } \\
\hline Rep & * & NS & $*$ & NS & NS & $*$ & $*$ & NS & NS \\
\hline location & NS & $*$ & $*$ & $*$ & NS & NS & NS & NS & $*$ \\
\hline population & $*$ & $*$ & $*$ & $*$ & $*$ & $*$ & $*$ & NS & NS \\
\hline loc $x$ pop & NS & NS & NS & NS & NS & NS & NS & NS & NS \\
\hline Rep & $*$ & $*$ & NS & NS & $\begin{array}{l}2006- \\
\text { NS }\end{array}$ & $\begin{array}{l}-- \\
*\end{array}$ & * & $\begin{array}{l}--\cdot \\
\mathrm{NS}\end{array}$ & $*$ \\
\hline location & $*$ & $*$ & $*$ & $*$ & NS & $*$ & $*$ & NS & $*$ \\
\hline population & $*$ & $*$ & $*$ & $*$ & $*$ & $*$ & $*$ & $*$ & NS \\
\hline row spacing & NS & NS & NS & NS & NS & $*$ & NS & NS & NS \\
\hline rs*pop & NS & NS & NS & NS & NS & NS & NS & NS & NS \\
\hline loc*pop & $*$ & $*$ & NS & NS & NS & $*$ & NS & NS & NS \\
\hline Loc*rs & $*$ & $*$ & NS & NS & NS & $*$ & NS & NS & NS \\
\hline loc*rs*pop & NS & NS & NS & NS & NS & NS & NS & NS & NS \\
\hline
\end{tabular}


Table 4. Soybean yield for two row spacings at three locations in Kansas in 2006.

\begin{tabular}{|c|c|c|c|c|}
\hline \multicolumn{5}{|c|}{ Row Spacing } \\
\hline & \multicolumn{2}{|c|}{$7.5 \mathrm{in}$} & 15 in & \\
\hline Location & $-\ldots-\ldots$ & $-\mathrm{Yic}$ & $\left.e^{-1}\right)-\ldots$ & Avg. \\
\hline Manhattan & 36 & $c^{\dagger}$ & $35 \mathrm{~cd}$ & 36 \\
\hline Ottawa & 44 & $\mathrm{a}$ & $41 \mathrm{~b}$ & 42 \\
\hline Rossville & 29 & $\mathrm{e}$ & $33 \mathrm{~d}$ & 31 \\
\hline \multirow[t]{2}{*}{ Avg. } & 36 & & 36 & 36 \\
\hline & $-\ldots--$ & - Pla & 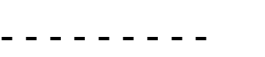 & Avg. \\
\hline Manhattan & 124487 & $a^{\dagger}$ & $112084 \mathrm{~b}$ & 118186 \\
\hline Ottawa & 105809 & $\mathrm{~b}$ & $93868 \quad \mathrm{c}$ & 99838 \\
\hline Rossville & 79611 & $\mathrm{e}$ & $82189 \mathrm{~d}$ & 75434 \\
\hline Avg. & 102009 & & 98533 & 100271 \\
\hline
\end{tabular}

$\dagger$ Means within a column or row for the same variable followed by a different letter differ at $\alpha=$ 0.05 . 
Table 5. Soybean yield components and plant characteristics at Manhattan, Ottawa, and Rossville, KS in 2005 and 2006.

\begin{tabular}{lccccc}
\hline \multicolumn{1}{c}{ Location } & Year & Pods plant $^{-1}$ & $\begin{array}{c}\text { Pods acre } \\
\left(\times 10^{-6}\right)\end{array}$ & $\begin{array}{c}\text { First Pod } \\
\text { Height (in) }\end{array}$ & $\begin{array}{c}\text { Seed Weight } \\
\left(\mathrm{mg} \mathrm{seed}^{-1}\right)\end{array}$ \\
\hline Manhattan & 2005 & $59.3 \mathrm{a}{ }^{\dagger}$ & $6.3 \mathrm{~b}$ & $4.3 \mathrm{c}$ & $140 \mathrm{a}$ \\
Ottawa & 2005 & $37.7 \mathrm{~b}$ & $4.4 \mathrm{c}$ & $6.7 \mathrm{a}$ & $133 \mathrm{~b}$ \\
Rossville & 2005 & $67.0 \mathrm{a}$ & $7.6 \mathrm{a}$ & $4.8 \mathrm{~b}$ & $128 \mathrm{c}$ \\
& & & & & \\
Manhattan & 2006 & $38.2 \mathrm{~b}^{\dagger}$ & $4.2 \mathrm{~b}$ & $4.5 \mathrm{a}$ & $158 \mathrm{a}$ \\
Ottawa & 2006 & $50.9 \mathrm{a}$ & $4.7 \mathrm{a}$ & $3.8 \mathrm{a}$ & $159 \mathrm{a}$ \\
Rossville & 2006 & $52.4 \mathrm{a}$ & $3.8 \mathrm{c}$ & $3.8 \mathrm{a}$ & $130 \mathrm{~b}$ \\
\hline
\end{tabular}

$\dagger$ Means within a column followed by a different letter differ at 0.05 . 
Table 6. Soybean plant heights for two row spacings at three locations in Kansas in 2006.

\begin{tabular}{ccccc}
\hline $\begin{array}{c}\text { Row } \\
\text { Spacing }\end{array}$ & Manhattan & Ottawa & Rossville & Avg. \\
\hline$-\ldots \ldots$ & $-\ldots .4 \mathrm{de}^{\dagger}$ & $27.4 \mathrm{~b}$ & $20.2 \mathrm{e}$ & 22.7 \\
7.5 & $20.2 \mathrm{e}$ & $29.4 \mathrm{a}$ & $20.9 \mathrm{de}$ & 23.5 \\
\hline 15 & $20.2 \mathrm{e}$ & 28.3 & 20.6 & \\
\hline
\end{tabular}

$\dagger$ Means followed by a different letter differ at $\alpha=0.05$ for Manhattan, Ottawa, and Rossville. 